\title{
Elk presence inside various-sized cattle exclosures
}

\author{
JEFFREY A. GROSS AND JAMES E. KNIGHT
}

Authors are graduate research assistant and professor, Department of Animal and Range Sciences, Montana State University, Bozeman, Mont. 59717.

\begin{abstract}
Accurate measures of the relative resource impacts from elk (Cervus elaphus) and cattle (Bos taurus and B. indicus) improve land management planning wherever these species cohabitate. Comparisons of utilization inside and outside cattle exclosures are often used for this purpose. The objectives of our study were to determine if (1) elk presence differed inside and adjacent to several different-sized cattle exclosures; (2) there was a relationship between cattle exclosure size and elk presence in exclosures; and (3) a minimum cattle exclosure size is appropriate for assessing elk impacts. Seven different-sized cattle exclosures (4.00, $2.00,1.00,0.50,0.25,0.10$, and 0.05 ha) were compared in western Montana during the spring of 1996 and 1997. Trackplots (1$\mathrm{m}^{2}$ areas cleared of vegetation) were used to detect elk presence. Chi-square tests indicated elk presence inside all exclosures was less $(P<0.10)$ than elk presence adjacent to the exclosures. Regression analysis indicated exclosure size and elk presence were correlated $(P<\mathbf{0 . 0 3})$. Elk presence inside exclosures increased with increasing exclosure size. Our results did not support the minimum exclosure size $(0.4 \mathrm{ha})$ recommended in the literature. Cattle exclosures larger than 4 ha appear needed to accurately measure relative resource impacts from elk and cattle; however, this does not ensure that an exclosure $>4.0$ ha in size will solve all of the problems associated with this technique.
\end{abstract}

Key Words: Cervus elaphus, exclosure size, livestock/wildlife relations, wild ungulates

Cattle (Bos taurus and B. indicus) and elk (Cervus elaphus) cohabitate extensive areas of western North America. When the condition or trend of these rangelands is unacceptable, and changes are considered to existing resource management plans, it is important to distinguish the relative impacts of elk versus cattle (Smith and Doell 1968). Accurate measurements of these relative impacts should improve planning efforts. The most widely used technique to delineate cattle and elk impacts on rangeland is the use of exclosures (Cook and Stubbendieck 1986, Laycock 1994).

Two types of exclosures are generally used. The first is a cattle exclosure constructed of 3 to 4 -strand barbed wire fence 0.8 to $1.0 \mathrm{~m}$ in height and the second is a big game exclosure constructed of 1.8 to $2.5 \mathrm{~m}$ tall woven wire fence (Young 1956, Austin et al. 1983, Austin and Urness 1986). By excluding cattle and/or elk from a given area, comparisons can be made between areas accessible to both cattle and elk (generally located adjacent to an exclosure), areas accessible to elk only (inside cattle exclosures),

Research was funded by the Montana Agricultural Experiment Station. Manuscript accepted 6 Sep. 1999.
Resumen

Las medidas precisas del impacto relativo del alce (Cervus ela phus) y el ganado (Bos taurus y Bos indicus) sobre los recursos ayudan a mejorar la planeación del manejo de los terrenos donde estas especies cohabitan. A menudo la comparación del grado de utilización dentro y fuera de exclusiones de ganado se utiliza para este propósito. Los objetivos de nuestro estudio fueron determinar si (1) la presencia del alce difirió dentro y en áreas adyacentes a exclusiones de ganado de diferente tamaño; (2) Si hubo una relación entre el tamaño de la exclusión para ganado y la presencia del alce en las exclusiones y (3) determinar el tamaño mínimo de exclusión para ganado necesario para evaluar el impacto del alce. Se compraron exclusiones para ganado de 7 tamaños diferentes $(4,2,1,0.5,0.25,0.1$ y 0.05 ha), la comparación se realizo en el oeste de Monatana durante la primavera de 1997 y 1998. Para detectar la presencia del alce se utilizaron parcelas de $1-\mathrm{m}^{2}$ en la cuales se limpio la vegetación. Las pruebas de Chi-cuadrada indicaron que la presencia del alce dentro de las exclusiones fue menor $(P<0.10)$ que en las áreas adyacentes. Los análisis de regresión indicaron que el tamaño de la exclusión y la presencia del alce estuvieron correlacionadas ( $P$ < 0.03). La presencia del alce dentro de las exclusiones se incremento al aumentar el tamaño de la exclusión. Nuestros resultados no confirman el tamaño mínimo de las exclusiones $(0.4$ ha) que es recomendado en la literatura. Las exclusiones de ganado mayores de 4 ha aparentemente requieren de medir en forma precisa los impactos relativos del alce y el ganado en los recursos; sin embargo, esto no asegura que una exclusión mayor de 4 ha resolverá todos los problemas asociados con esta técnica.

and areas to which neither have access (inside big game exclosures).

This approach assumes that elk accessibility to the area inside the cattle exclosure is unimpeded by the fence. If elk are not freely entering the cattle exclosure, differences between the area inside and adjacent to the cattle exclosure may lead to overestimation of impacts due to cattle alone.

Young (1958) suggested that elk were less likely to enter small livestock exclosures. Several other sources also have addressed the effects of exclosure size on the likelihood that wild ungulates will enter an exclosure (Young 1956, Julander 1958, Tueller and Tower 1979, Yoakum et al. 1980, Cook and Stubbendieck 1986, Laycock 1994). These sources suggest livestock exclosures should be a minimum of 0.4 ha in size in areas populated by wild ungulates. Young (1956), Julander (1958), and Tueller and Tower (1979) are the only sources we were able to find that scientifically tested wild ungulate presence in livestock exclosures; however, none of these sources tested elk presence in exclosures. 
The purpose of our study was to determine if elk presence differed inside and adjacent to several different-sized cattle exclosures. We also wanted to determine if there was a relationship between elk presence inside the exclosures and exclosure size. Finally, we wanted to determine how large a cattle exclosure must be to facilitate equal elk presence inside and adjacent to the exclosure.

\section{Materials and Methods}

\section{Study Area}

In 1995, livestock exclosures were constructed in 2 pastures on the Blackfoot Clearwater Wildlife Management Area approximately $70 \mathrm{~km}$ northeast of Missoula, Mont. Pasture A was about 450 ha and pasture B was about 250 ha. Vegetation in Pasture A was dominated by timothy (Phleum pratense L.) and vegetation in Pasture B was dominated by rough fescue (Festuca scabrella Torr.). These pastures are part of an elk winter range, but due to snow pack from January through April the pastures are not used by elk until spring.

\section{Study Design and Exclosure Layout}

Square exclosures were constructed of 3 strands of barbed wire with the top and bottom strands 1.0 and $0.25 \mathrm{~m}$ above the ground. Metal t-posts, spaced $6.0 \mathrm{~m}$ apart, supported the wire between wood corner posts.

A randomized block design was used. In Pasture A, 2 sets of 7 different-sized exclosures were randomly located along a line with a minimum of $50.0 \mathrm{~m}$ between each exclosure (Fig. 1). Exclosures were $0.05,0.10,0.25,0.50,1.00,2.00$, and 4.00 ha in size. In Pasture B, 2 sets of 3 different-sized exclosures were randomly located along a line with a minimum of $50.0 \mathrm{~m}$ between each exclosure. Exclosures were $0.05,0.50$, and 2.00 ha in size.

Each transect in the 2 pastures represented a block for a total of 4 blocks. Each exclosure size represented 1 treatment for a total of 7 treatments. The experimental unit was defined as an individual cattle exclosure with 2 replicates of the 0.10 , $0.25,1.00$ and 4.0-ha exclosure sizes, and 4 replicates of the $0.05,0.50$, and 2.00-ha exclosure sizes. Exclosure sizes tested were chosen to reflect sizes equal to, above, and below those recommended by Julander (1958), Tueller and Tower (1979), Yoakum et al. (1980), and Young (1956). Vegetative condition, species

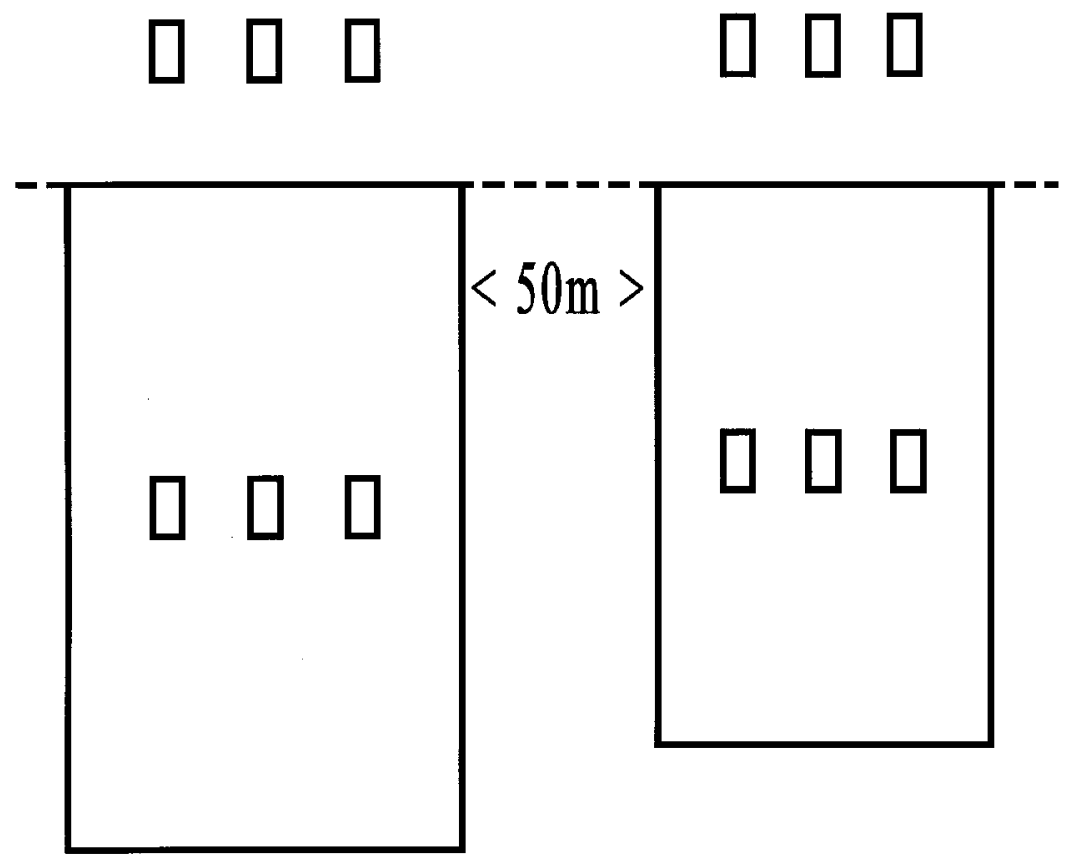

Fig. 1. Example of exclosure and trackplot layout.

composition, exposure to grazing, slope and exposure were similar inside and adjacent to each exclosure.

\section{Monitoring Elk Presence}

Elk presence inside and adjacent to each exclosure was monitored with trackplots. Trackplots (1- $\mathrm{m}^{2}$ areas cleared of vegetation to expose bare soil) were evenly spaced across the center of each exclosure parallel to the line the exclosures are located along (Fig. 1). Three track plots were located in the $0.05,0.10,0.25,0.50$, and 1.00-ha exclosures, 5 in the 2.00-ha exclosures, and 7 in the 4.00-ha exclosures. An equal number of trackplots were located $25 \mathrm{~m}$ outside each exclosure, spaced equally to those inside the exclosure. Trackplots were monitored every 2-4 days when the ground was free from snow and elk were present in the study area (midApril to mid-June). Data was collected on 13 different days in 1996 and 20 different days in 1997.

When 1 or more elk hoof prints were found in a trackplot the trackplot was considered hit. Total number of hit trackplots inside and adjacent to each individual exclosure were recorded on each day data were collected. Elk hoof prints were cleared from trackplots each day data were collected. Total number of trackplots hit inside each individual exclosure and total number of trackplots hit adjacent to each individual exclosure were pooled at the end of each year. If there were no track- plots hit during an observation, data from that observation was dropped from the final data set. Zero hits during an observation indicated there were inadequate numbers of elk in the vicinity of the exclosure to make a valid comparison of elk presence inside and adjacent to the exclosure. If these observations were included in our data set they would have indicated equal elk presence, which could have biased our results toward equal use. Mean number of trackplots hit inside and adjacent to each exclosure size tested were used to quantify elk presence.

Trackplots hit were converted to a proportion. Proportion of trackplots hit inside an exclosure equaled the number of trackplots hit inside an individual exclosure divided by the total number of trackplots hit inside and adjacent to the same individual exclosure. This eliminated bias associated with variability of the relative area sampled by trackplots in different sized exclosures. For example, a proportion allows analysis using a 2-ha exclosure with 5 trackplots and a 4-ha exclosure with 7 trackplots.

\section{Statistical Analysis}

Chi-square was used to compare elk presence inside and adjacent to each size of exclosure tested. Mean number of trackplots hit inside and adjacent to each exclosure size was used in this test. All values were tested at $\mathrm{P}<0.10$. 


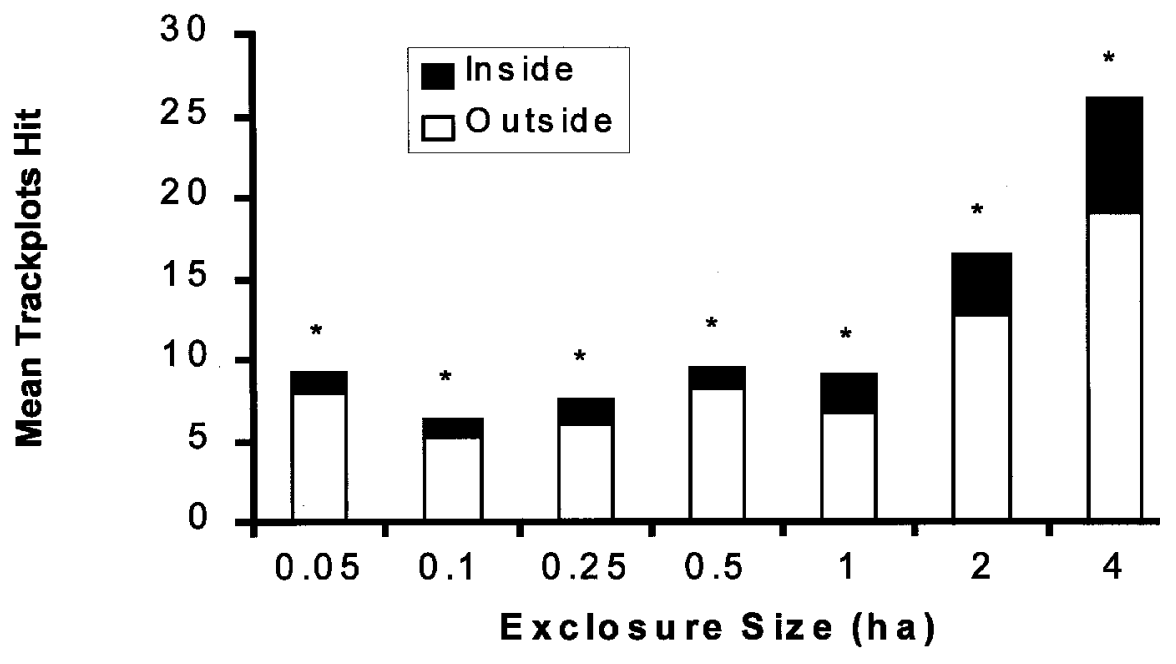

Fig. 2. Elk presence inside and adjacent to exclosures on the Blackfoot Clearwater Wildlife Management Area, Montana, April-June, 1996-97. Asterisk* indicates a significant chisquare value, $\mathrm{P} \leq \mathbf{0 . 1 0}$.

Regression analysis was conducted, using the general linear model procedure of SAS (1985) to determine if there was a correlation between trackplots hit and exclosure size $(\mathrm{P}<0.10)$.

\section{Results and Discussion}

\section{Elk Presence Inside and Adjacent to Exclosures}

Elk presence adjacent to exclosures was greater $(\mathrm{P}<0.10)$ than elk presence inside exclosures (Table 1, Fig. 2). An explana-

Table 1. Chi-square values comparing elk presence inside and adjacent to exclosures.

\begin{tabular}{lrcc}
\hline \hline Exclosure Size & $\chi^{2}$ & $\begin{array}{c}\text { Degrees of } \\
\text { Fredom }\end{array}$ & P-value \\
\hline (ha) & & & \\
0.05 & 16.0 & $5^{1}$ & 0.007 \\
0.10 & 6.6 & $3^{2}$ & 0.085 \\
0.25 & 2.7 & $1^{3}$ & 0.100 \\
0.50 & 13.3 & 3 & 0.004 \\
1 & 9.6 & 3 & 0.022 \\
2 & 18.3 & 3 & 0.003 \\
4 & 11.6 & 3 & 0.009 \\
${ }^{1} \chi^{2} 0.1$ with 5 d.f. $=9.2$ & & \\
${ }^{2} \chi^{2} 0.1$ with 3 d.f. $=6.3$ & & \\
${ }^{3} \chi_{0.1}^{2}$ with 1 d.f. $=2.7$ & &
\end{tabular}

tion of why elk presence was less inside our exclosures may be that sometimes elk simply choose not to cross fences. We have observed elk approach a fence and instead of jumping over it, parallel the fence in an apparent attempt to find a way around. In addition, the 4 sides of an exclosure may present a greater visual obstacle than a single stretch of fence (pasture perimeter fence). This increased visual obstacle may increase an elk's reluctance to cross an exclosure fence.

\section{Elk Presence in Different-Sized Exclosures}

Our regression analysis $\left(\mathrm{R}^{2}=0.33\right)$ indicated elk presence inside exclosures increased as exclosure size increased (Fig. $3)$. A possible explanation is that as exclosure size increases the elk is less likely to see all sides of the exclosure, which could decrease the visual obstacle presented by the exclosure and increase the likelihood that an elk will enter an exclosure.
The coefficient of determination for our regression was 0.33 . The logistics of this experiment limited our sample size, which restricted the level of power. This may partially explain the low coefficient of determination. Our model indicates that an exclosure needs to be larger than 4 ha in size to facilitate equal elk presence inside and adjacent to the exclosure (Fig. 3). We are not suggesting that simply building an exclosure $>4.0$ ha in size will solve all of the problems associated with this technique.

Young (1956) was the only study we found that examined the effect of more than one exclosure size on wild ungulate presence inside exclosures. Young (1956) compared livestock exclosures from $<0.2$ to 1.7 ha in size and concluded that elk presence differed among exclosure sizes. Young's conclusion that elk presence inside exclosures increases with increasing exclosure size is supported by our results. However, Young's conclusion that a 0.4ha exclosure had equal elk presence inside and adjacent to it was not supported by our results.

\section{Conclusions and Management Implications}

The results of this study have important management implications to federal, state, and private resource managers in areas with elk and cattle. Accurate measures of relative resource impacts from cattle and elk are needed to make proper management decisions (Wisdom and Thomas 1996). Previous management decisions

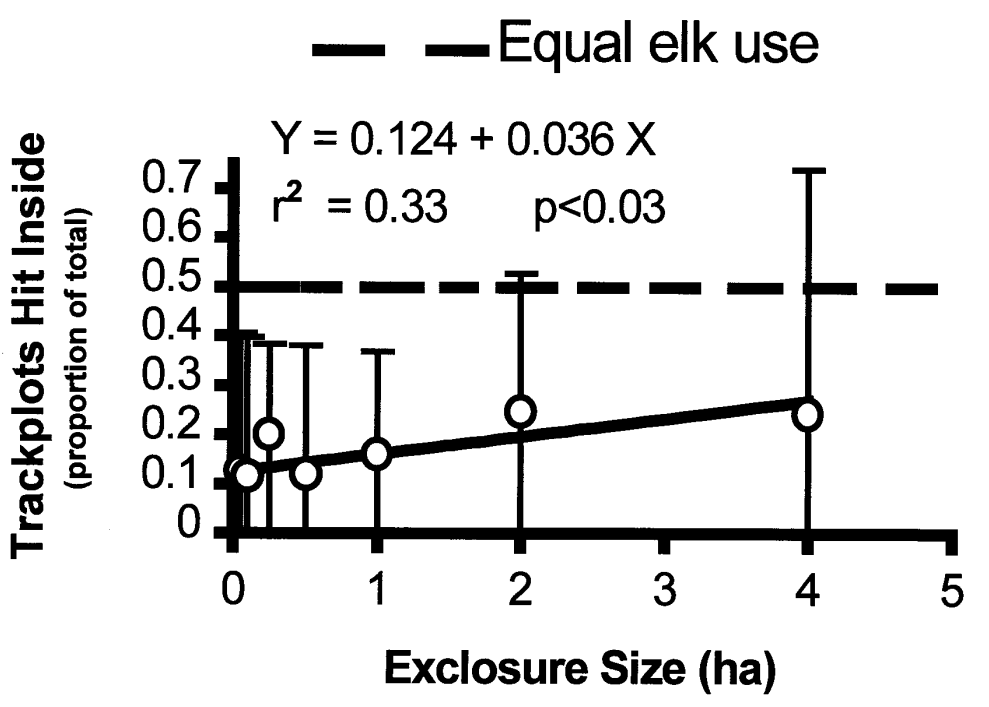

Fig. 3. Proportion of total trackplots hit inside exclosures, on the Blackfoot Clearwater Wildlife Management Area, Montana, April-June, 1996-97. 
based on information from cattle exclosures may have been incorrect, especially if cattle exclosures were $\leq 4.0$ ha in size.

Logistically, it may be impractical to build an exclosure large enough to minimize the effects of size on elk presence and there is no guarantee that an exclosure $>4.0$ ha in size will eliminate all of the problems associated with this technique. The reluctance of elk to cross fences could still pose a problem no matter how large an exclosure is built. A solution to this may be to drop the fence of the exclosure when cattle are not present. This could be applicable to an elk wintering area that is being grazed by cattle only during the growing season. Elk are generally dispersed and in low numbers in these areas when cattle are present (during the growing season) and concentrated when cattle are absent (winter) (Lyon 1985). Another solution may be to erect an exclosure when elk are not present in high densities (growing season), collect vegetation data at the end of the growing season, and construct a new exclosure in a new location the following growing season. Although cattle exclosures may be used as an effective management tool to separate elk and cattle impacts, precautions should be implemented to minimize or account for the potential biases resulting from the reluctance of elk to cross cattle fences.

Additional questions could be explored concerning this technique. How do elk use exclosure sizes above 4.0 ha? How is elk use effected by fence design (fence height, fence materials, exclosure shape and layout), and exclosure location in the landscape (vegetation condition, slope and exposure)?

\section{Literature Cited}

Austin, D.D. and P.J. Urness. 1986. Effects of cattle grazing on mule deer diet and area selection. J. Range Manage. 39:18-21.

Austin, D.D., P.J. Urness, and L.C. Fierro. 1983. Spring livestock grazing effects on crested wheatgrass regrowth and winter use by mule deer. J. Range Manage. 36:589-593.

Cook, C.W. and J. Stubbendieck (eds.). 1986. Range research: Basic problems and techniques. Soc. Range Manage., Denver, Colo.

Julander, O. 1958. Techniques in studying competition between big game and livestock. J. Range Manage. 11:18-21.

Laycock, W.A. 1994. Implications of grazing vs. no grazing on today's rangelands, p. 250280. In: M.V. Vavra, W.A. Laycock, and R.D. Pieper (eds.), Ecological implications of livestock herbivory in the West. Soc. for Range Manage., Denver, Colo.
Lyon, L.J. 1985. Elk and cattle on the national forests: A simple question of allocation or a complex management problem? Western Wildlands 11:16-19.

SAS Institute Inc. 1985. SAS userís guide: Statistics, version 5 edition. Cary, N.C.: SAS Institute Inc.

Smith, A.D. and D.D Doell. 1968. Guides to allocating forage between cattle and big game on big game winter range. Utah State Division of Fish and Game, Salt Lake City, Utah.

Tueller, P.T. and J.D. Tower. 1979. Vegetation stagnation in three-phase big game exclosures. J. Range Manage. 32:258-263.

Wisdom, M.J. and J.W. Thomas. 1996. Elk, p.157-181. In: Paul R. Krausman (ed.), Rangeland Wildlife. Soc. for Range Manage., Denver, Colo.

Yoakum, J., W.P. Dasmann, H.R. Sanderson, C.M. Nixon, and H.S. Crawford. 1980. Habitat improvement techniques, p. 329-404. In: S. D. Schemnitz (ed.), Wildlife management techniques manual. Wildl. Soc., Inc. Bethesda, Md.

Young, S. 1956. Survey and evaluation of big game exclosures in Utah. Dep. Information Bull. 24. Salt Lake City, Utah.

Young, S. 1958. Exclosures in big game management in Utah. J. Range Manage. 11:186190. 